\footnotetext{
'Department of Sheep and Goat Breeding, ${ }^{2}$ Department of Mathematical and Statistical Methods. Agricultural University of Poznani, Poland
}

\title{
A comparison of alternatives of milk recording schemes for dairy sheep
}

\begin{abstract}
Summary
A total of 307 lactations of ewes from synthetic line (13/16 East Friesian Milk Sheep, 3/16 Polish sheep breeds) were investigated. Ewes were milked after weaning, starting on the $60^{\text {th }}$ day of lactation, for the period of four months. Milk recording was conducted using the A30 scheme during the morning and afternoon milkings. Twenty one simplified milk recording schemes were investigated, taking into account the data from 4 or 6 control milkings, and estimating the differences between milk production, protein and fat contents on the basis of the simplified and the A30 methods. The accuracy of the methods to estimate milk (protein, fat) yields was verified using the pairwise test. Among the tested 4-measurement methods, the most useful - in terms of the accuracy of milk, protein and fat yield estimations - were models, in which milk recording is conducted once a month, only in the morning or afternoon. The application of such methods does not result in the deterioration of accuracy of milk recording for sheep and makes it possible to lower the costs connected with recording by approximately $50 \%$.
\end{abstract}

Key Words: sheep, milk recording, milk composition

\section{Zusammenfassung}

Titel der Arbeit: Vergleich alternativer Methoden der Milchleistungsprafung bei Milchschafen Es wurden insgesamt 307 Laktationen der Mutterschafe aus der synthetischen Linie (13/16 Ostfriesisches Milchschaf,
$3 / 16$ poinische Schafrassen) untersucht. Die Mutterschafe wurden nach dem Absetzen der Lammer, ab 60. Laktationstag, aber vier Monate, gemolken. Die Milchleistungsprufung wurde nach der A30-Methode, beim Morgenvereinfachte Milchleistungsprilfungeshend der Daten von 4 oder 6 Milcheinzelprifungen wurden einundzwanzig berenterste die Differenzen zwischen der Milch-, Protein- und Fettmenge berechnet und nach der vereinfachten und A-30 Methode geschatzt. Die Genauigkeit der Methoden fur die Schattzung und bei Berdicksichtigund Fettmenge wurde mit dem Pairwise-Test verifiziert. Von den getesteten 4-Prufungsschematas Milchiein die Modelle die beste Eígnung gezeigi, bei denen die Milchieistungspriffung nur einmal im Monat durchgefuhrt wurde - entweder nur am Morgen oder nur am Abend die Kosten ihrer Durchfithrung aenauigkeit der Milchleistungsprufung der Mutterschafe nicht herabgeselzt und lisst

Schlusselworter: Schaf, Milchleistungsprufung, Milchzusammensetzung

\section{Introduction}

In many countries with a high standard of sheep breeding, profits gained from sheep milk are second only to the revenue from the sale of slaughter lambs. We are witnessing the same trend in Poland, where there is an increasing interest in this type of production as an alternative source of income in sheep breeding, especially among breeders in the lowland regions of our country (WÓJTOWSKI et al., 1999). A signifieant factor affecting the standard of production in case of milking sheep is the adequate development of milk recording schemes (GUT et al., 1999). The recording 
results and a good selection programme have contributed to a considerable increase in the milk yields in the European Union countries of the Mediterranean region (BARILLET et al., 1996).

Monthly recording of two daily milkings (the " $\mathrm{A}$ " method) is the standard method for dairy cattle (GABINA et al., 1986). The fixed costs of the A method in relation to the commercial value of the final product are about 2 or 3 times larger in milking sheep than in cattle (BARULLET and ROUSELLY, 1987; SANNA et al., 1994). The simplified milk recording schemes present many potential advantages including: lower costs for the dairyman, less disruption of daily farm routine and an increased number of herds participating (DICKINSON and MC DANIEL, 1970; WÓJTOWSKI et al., 1999).

A simplification of the official method for milk recording is A30; it provides monthly recordings of two daily milkings, which can be achieved by:

- Measuring two daily milkings every 45 and 60 days (A45 and A60)

- Measuring only one milking a day (alternately morning and afternoon, AT

A great number of researchers (BARILLET et al., 1987; BOULOC et al.4 1991, Wojtowski and Gut, 1996) have found that the alternate methods are more exact than the $\mathrm{A} 45$ and the $\mathrm{A} 60$ methods.

\section{Material and Methods}

A total of 307 lactations of ewes a from synthetic line (13/16 East Friesian Milk Sheep, 3/16 Polish sheep breeds) at the Experimental Farm of the Agricultural University of Poznań, from years 1997-1999 were utilised for this study. Four times, every 30 days, the milk yields were recorded and milk samples for the estimation of protein and fat contents were collected at morning and afternoon milkings, from the $60^{\text {th }}$ day until the $180^{\text {th }}$ day after lambing (the end of lactation). Data from each 8 milk recordings were collected for all ewes included in the study.

Twenty one simplified milk recording schemes were investigated, taking into account the data from 4 or 6 control milkings, and estimating the differences between milk production, protein and fat contents on the basis of the simplified and the A30 methods.

The Daily Milk Yield (DMY) in the models, in which milk recording was to be done once a day, was calculated by doubling the morning or afternoon milk yields (models $6 \mathrm{~d}, 7 \mathrm{~d}, 8 \mathrm{~d}, 9 \mathrm{~d}$ ) or by multiplying the morning or afternoon milk yields by an adjustment factor $\mathrm{K}_{\mathrm{k}}$ (models $6 \mathrm{k}, 7 \mathrm{k}, 8 \mathrm{k}, 9 \mathrm{k}, 13 \mathrm{k}, 14 \mathrm{k}$ ). A similar adjustment factor was used e.g. by WIGGANS (1981), DE LORENZO and WIGGANS (1986), BOULOC et al. (1991). The $K_{k}$ adjustment factor was used because, of all the procedures of calculation, that proposed by GIACCONE et al. (1996) and PORTOLANO et al. (1997), it was the most exact, irrespective of the method tested.

The adjustment factor $K_{k}$ was caiculated both for the morning recording $\left(\mathrm{K}_{\mathrm{km}}\right)$, and for the atternoon one $\left(\mathrm{K}_{\mathrm{ka}}\right)$, according to the following formulas:

$$
K_{k_{m}}=\frac{M T M Y+A T M Y}{M T M Y}
$$


$K_{b_{a}}=\frac{M T M Y+A T M Y}{A T M Y}$

where: MTMY - Morning Total Milk Yield ATMY - Afternoon Total Milk Yield

The production of protein and fat was calculated for each ewe in the way analogous to that used for milk yields.

In models 11 and 12 , in which the $3^{\text {rd }}$ and $4^{\text {th }}$ or $5^{\text {th }}$ and $6^{\text {th }}$ milk recordings were omitted (Tab. 1), the figures for milk (protein, fat) yield level obtained during the previous recording were multiplied by the double number of days (i.e, 60). In turn, in models $11 \mathrm{a}$ and $12 \mathrm{a}$, data from both milk recordings next to the omitted recording were multiplied by the number of days increased by $50 \%$ (i.e. $30+15$ ).

Table I

The rested milk recording schemes (Getestete Milchleistungsprufungsschemata)

\begin{tabular}{|c|c|c|c|c|c|c|c|c|}
\hline \multirow{3}{*}{$\begin{array}{l}\text { Milking recording scheme } \\
\text { Milchleistungsprufungschema }\end{array}$} & \multicolumn{8}{|c|}{ No of measurement "(Anzahl der Prufungen) } \\
\hline & \multicolumn{2}{|c|}{ I } & \multicolumn{2}{|c|}{ II } & \multicolumn{2}{|c|}{ III } & \multicolumn{2}{|c|}{ IV } \\
\hline & M & A & M & A & M & A & M & A \\
\hline & 1 & 2 & 3 & 4 & 5 & 6 & 7 & 8 \\
\hline A30 & + & + & + & $t$ & + & + & $t$ & + \\
\hline $2(\mathrm{~A} 60)$ & + & + & $=$ & 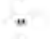 & + & + & - & - \\
\hline $3(\mathrm{~A} 60)$ & - & - & + & + & - & - & + & + \\
\hline 4 & - & - & + & + & + & + & - & - \\
\hline 5 & + & + & - & - & - & - & + & + \\
\hline 6d; 6k (ATM30) & + & - & - & + & + & - & - & + \\
\hline $7 \mathrm{~d} ; 7 \mathrm{k}(\mathrm{ATS} 30)$ & - & + & + & - & - & + & + & - \\
\hline $8 \mathrm{~d} ; 8 \mathrm{k}$ & + & - & + & $\cdot$ & + & - & + & - \\
\hline 9d; 9k & - & + & - & + & - & + & - & + \\
\hline 10 & + & + & + & + & + & + & - & $\therefore$ \\
\hline $11 ; 11 a$ & + & $\div$ & + & + & - & - & + & + \\
\hline $12 ; 12 \mathrm{a}$ & + & + & - & - & + & + & + & + \\
\hline $13 \mathrm{~d} ; 13 \mathrm{k}$ & + & - & + & + & + & + & + & - \\
\hline $14 \mathrm{~d} ; 14 \mathrm{k}$ & - & + & + & + & + & + & - & + \\
\hline $\begin{array}{l}\text { M- moming milking (Morgengem } \\
\text { + - used control recording (angewan } \\
\text { d - morning (afternoon) milk (protei } \\
\text { (Protein-, Fett-) menge multiplizi } \\
\text { - - morning (afternoon) milk (protei } \\
\text { (Protein-. Fetl-) menge multiplizi } \\
\text { - multiplier adjusting the consecut } \\
\text { Öberbruckungsrechnung) }\end{array}$ & $\begin{array}{l}\text { noon } \\
\text { afung }\end{array}$ & $g(A)$ & melk & $\begin{array}{l}\text { lech- } \\
\text { ilch- }\end{array}$ & & & & \\
\hline
\end{tabular}

In order to determine the accuracy of the simplified milk recording schemes, for each ewe a difference was calculated between the total milk (protein, fat) yield established using the reference method and the yield estimated with the use of the simplified scheme.

$D=A_{1}-A_{n}$

where: $A_{1}$ - milk (protein, fat) yield determined using the reference method (A30),

$A_{n}$ - milk (protein, fat) yield estimated with one of the simplified methods $(n=21)$

The statistical analysis was conducted using the pairwise test (MORRISON, 1967) 
with the statistical package SAS ver. 6.12 (1996).

The following hypothesis was proposed:

$H_{0}: \mu_{1}-\mu_{2}=\delta_{0}$ assuming that $\delta_{0}=0$; (this hypothesis says that the compared expected values are equal, i.e. $\mu_{1}=\mu_{2}$ )

against an alternative hypothesis saying that the difference equals $\delta_{1}$,

i.e. $H_{1}: \mu_{1}-\mu_{2}=\delta_{1}$, where $\delta_{1} \neq 0$ and $\delta_{0} \neq \delta_{1}$.

Results and Discussion

Table 1 presents a review of the investigated models of simplified milk recording schemes, including the control milking marked for each model. Table 2 presents a comparison of accuracy between the methods used and the official method for milk recording schemes in sheep, the A30 method, in terms of milk, protein and fat yield measurements, where the differences are expressed in $\mathrm{kg}$ and in percentages.

Table 2

Differences between the $\mathrm{A} 30$ and the simplified milk recording schemes (Differenzen zwischen der $\mathrm{A} 30$ und der vereinfachten Milchleistungsprufungsschematas)

\begin{tabular}{|c|c|c|c|c|c|c|}
\hline \multirow{2}{*}{$\begin{array}{l}\text { Milking recording } \\
\text { scheme } \\
\text { (Schema der } \\
\text { Milchleistungsprüfung) }\end{array}$} & \multicolumn{2}{|c|}{$\begin{array}{l}\text { Total milk yield } \\
\text { (Gesamte Miichmenge) } \\
\text { Difference (Differenz) }\end{array}$} & \multicolumn{2}{|c|}{$\begin{array}{l}\text { Total protein production } \\
\text { (Gesamte Proteinmenge) } \\
\text { Difference (Differenz) }\end{array}$} & \multicolumn{2}{|c|}{$\begin{array}{l}\text { Tofal fat production } \\
\text { (Gesamte Fettmenge) } \\
\text { Difference (Differenz) }\end{array}$} \\
\hline & $\mathrm{kg}$ & $\%$ & $\mathrm{~kg}$ & $\%$ & $\mathrm{~kg}$ & $\%$ \\
\hline A30 & 0 & 0 & 0 & 0 & 0 & 0 \\
\hline $2(\mathrm{~A} 60)$ & 9.926 * & 14.83 का & 0.514 *b & $13,10^{\mathrm{kk}}$ & $0.451 *$ & $10.71 * *$ \\
\hline $3(\mathrm{~A} 60)$ & $-9.926+k$ & $-14.83 \times$ & $-0.514 * 0$ & $-13.10=0$ & $-0.451=0$ & $-10.71+4$ \\
\hline 4 & $2.667 *$ & $3.32 *$ & 0,107 & 2.32 & -0.131 & -2.61 \\
\hline 5 & $-2.667^{b}$ & -3.32 & -0.107 & -2.32 & 0.131 & 2.61 \\
\hline $6 \mathrm{~d}$ & 0.864 & 1.41 & 0.028 & 0.95 & -0.061 & -1.26 \\
\hline $6 k$ (ATM30) & -0.482 & -0.52 & -0.052 & -1.00 & 0.004 & 0.21 \\
\hline $7 d$ & -0.864 & -1.41 & -0.028 & -0.95 & $0.06 !$ & 1.26 \\
\hline $7 \mathrm{k}($ ATS30) & 0.484 & 0.67 & 0.048 & 1.04 & -0.004 & $-0,14$ \\
\hline $8 \mathrm{~d}$ & $9.296 * *$ & 12.34 & $0.543^{* 中}$ & 12.38 & 0.021 & -0.27 \\
\hline $8 \mathrm{k}$ & -0.020 & -0.43 & 0.013 & -0.03 & 0.035 & 0.11 \\
\hline $9 d$ & $-9.296^{* *}$ & -12.34 & $-0.543 * \psi$ & $-12.38 * \alpha$ & $-0,021$ & 0.29 \\
\hline $9 \mathrm{k}$ & 0.023 & 0.58 & -0.016 & 0.07 & -0.034 & -0.04 \\
\hline 10 & 6.297 स & 9.07 \% & 0.310 & $7.71 * *$ & $0.160^{\circ}$ & $4.05^{*}$ \\
\hline 11 & 4.036 * & $6.39 * t$ & $0.135^{*}$ & $3.70^{\circ}$ & 0.152 & $3.97 *$ \\
\hline $11 \mathrm{a}$ & -1.130 & -1.34 & -0.088 & $-2,00$ & -0.004 & -0.04 \\
\hline 12 & $3.629^{*}$ & $5.76^{46}$ & $0.204^{\text {ces }}$ & $5.39 \& 4$ & $0.291^{*}$ & $6.66 * 0$ \\
\hline $12 a$ & -0.204 & -0.32 & $-0.03 \mathrm{~S}$ & 0.84 & 0.070 & 1.34 \\
\hline $13 \mathrm{~d}$ & 4.627 to & $6.02 \%$ & $0.256 *$ & 5,69 th & 0.029 & 0.19 \\
\hline $13 \mathrm{k}$ & 0.071 & -0.22 & -0.003 & -0.39 & 0,034 & 0.38 \\
\hline $14 \mathrm{~d}$ & $-4.627 * 4$ & $-6.02 *$ & -0.256 & $-5.69 \times 4$ & -0.029 & -0.19 \\
\hline $14 \mathrm{k}$ & -0.101 & 0.29 & 0.004 & 0.51 & -0.034 & -0.32 \\
\hline
\end{tabular}

Among the 21 investigated methods, ten did not differ from the $\mathrm{A} 30$ method assumed as standard, both in terms of accuracy of milk yield measurements, and the corresponding data for protein and fat. The most accurate result, differing from the one obtained using the A30 method by only $0.22 \%$ (for milk yield), $0.39 \%$ (for protein production) and $0.38 \%$ (for fat production, respectively), was given by the $13 \mathrm{k}$ method with 6 recordings. 
The 6-recording methods, similar to the A30 method as far as estimation accuracy is concerned (i.e.11a, 12a, 13k, 14k; P>0.05), were slightly better than those based on 4 recordings, i.e. $6,6 \mathrm{k}, 7,7 \mathrm{k}, 8 \mathrm{k}$ and $9 \mathrm{k}$. The absolute difference in the estimated milk yields between these groups of models ranged generally from 0.2 to $0.4 \%$.

In all investigated models, a better accuracy of estimation was obtained using the $\mathrm{K}_{k}$ adjustment factor.

Taking into consideration the accuracy of the estimated levels of milk, protein and fat production in the 4 -recording schemes, it turned out that the most accurate were the $8 \mathrm{k}$ and $9 \mathrm{k}$ models. These are measurements based on one recording daily (either morning or afternoon) conducted every 30 days.

Two of the models tested in this study: 6k (ATM30) and 7k (ATS30), are classical alternate methods, as AT is measuring only one milking a day, alternately morning or afternoon, every 30 days. Their accuracy in terms of milk yield measurements is similar to that obtained in the $8 \mathrm{k}$ and $9 \mathrm{k}$ models $(D=-0.48 \mathrm{~kg}$ and $0.49 \mathrm{~kg}$ of milk, respectively; equivalent to $-0.52 \%$ and $0.67 \%$, respectively). The precision of protein production estimation using those models, however, is considerably lower than that obtained in the $8 \mathrm{k}$ and $9 \mathrm{k}$ models $(\mathrm{D}> \pm 1 \%$, Table 2$)$.

The accuracy of milk yield estimation using the A60 method developed in this study, with respect to the $A 30$ method $(D=-14.83 \%$; Table 2), was worse than those achieved by NARDONE et al. (1991) for milking sheep ( $D=8.8 \%$ ), as well as GIACCONE et al. (1996) for a flock of goats $(\mathrm{D}=6.48 \%)$. Better accuracy was also given by PORTOLANO et al. (1997), who estimated 345 lactations of Comissana sheep $(\mathrm{D}=-6.42 \%)$. In both papers, the estimated differences between milk yields calculated using the A30 method, and the ATM30 and ATS 30 methods were almost identical as the one arrived at in this study. PORTOLANO et al. (1997) reported $\mathrm{D}=0.80 \%$ and $\mathrm{D}=-0.57 \%$, respectively.

GIACCONE et al. (1996) found that if they used the $\mathrm{K}_{\mathrm{k}}$ adjustment factor, the alternate methods beginning with the morning milking were more exact than the methods that began with the afternoon milking. The results in this study are consistent with the above frend (Table 2). From a practical point of view, the procedure raking into consideration the adjustment factor in model $\mathrm{K}_{k}$ tends to be more labour consuming only to a limited degree, thus resulting in a relatively small increase in the recording costs. The role of the recording supervisor in that case is limited only to a single individual milk recording (either the morning one or the afternoon one) and a single (morning or afternoon) measurement of the total amount of milk in the container collecting yields from the evaluated ewes.

\section{Conclusion}

This study showed the feasibility of simplifying the standard milk recording scheme (the A30 method) in the work on the creation of a synthetic line of sheep with a high percentage (13/16) of the Friesian sheep genotype. Among the tested 4-measurement methods, the most useful - in terms of the accuracy of milk, protein and fat yield estimation - were the models, in which milk recording is conducted once a month, only in the morning or afternoon. The application of such methods does not result in the deterioration of accuracy of milk recording for sheep and makes it possible to 
lower the costs connected with recording by approximately $50 \%$. Research results indicated a necessity to include in the developed models other data apart from yields, e.g. the production of basic milk components. Moreover, they confirmed the effectiveness of the $\mathrm{K}_{\mathrm{k}}$ adjustment factor in the sheep milk recording schemes using simplified methods.

\section{References}

BARILLET, F; BOICHARD D; ASTRUC J.M.; BONAITI B, Validation of estimated genetic trend in French Lacune dairy sheep evaluation. In: Proc. $30^{\text {th }}$ Biennial Session of ICAR, Veldhoven, The Netherlands, June 23-28, 1996, EAAP Publication No. 87, 291-296. 1996

BARILLET, F; ROUSELLY, $M$ : Mejora genetica del ovino lecchero en Francia: balance y perspectivas. Revista ITEA, 72 (1987), 3-22

BARILLET, F.; BOICHARD D.: BOULOC N.; GABINA D.; PIACERE A.; ROUSSELY M.: Prcisionei mise en oeuvre dans les especes ovines et caprines de méthodes simplifiés de contrôle laítier adaprées (leur finalité. 38ème Réunion Annuelle de la Fédération Européenne de Zootechnie, Lisbonne, Portugal, 28.09. - 01.10.1987

BOULOC N. ; BARILLET F. ; BOICHARD D. ; SIGWALD J.P.; BRIDOUX G. :

Etude des possibilités d'allègement du contrôle laitier officielchez les caprins. Ann. Zootech., 40 (1991), $125-$ 139

DE LOREZNO M.A.; WIGGANS G.R:

Factors for estimating daily yield of milk, fat and protein from a single milking for herds milked twice a day, J. Dairy Sci., 69 (1986), 2386-2394

DICKINGSON F.N.; MCDANIEL B.T:

Single milking yields versus 24 -hour yield for estimating lactation milk production by the test interval method. J. Dairy Sci., 53 (1970), 200-207

GABIN $A_{4}, D$; URARTE, E; ARRANZ, J.: Metodos de simplificacion del control lechero cuantitativo. Invest. Agraria Prod. Anim., 1 (1986), 59-170

GIACCONE, P.; PORTOLANO, B.; TODARO, M.; LETO, G.; Semplificazione dei metodi di controllo della produzione di latte nelia specie caprina. Zoot. Nutr. Anim., 22 (1996), 169-178

GUT, A.; WÓJTOWSKI, J.; ŚLÓSARZ, P.; STRABEL, T.:

Elaboration of a sheep milk recording method in the region of Lowiand Poland. $6^{\text {th }}$ Internationai Symposium on the Milking of Small Ruminants. Athens, Greece, 26.09. - 01.10.1998. Wageningen Pers. EAAP Publication No 95: 438-440. 1999

MORRISON D.F. Multivariate statistical methods. McGraw - Hill Book Company, USA 1967

PORTOLANO, B.; TODARO, M.; SPATAFORA, F; BONO, G; MARGOTTA, S; GIACCONE P.: Simplification of milk recording scheme in Comisana milking sheep. Agr. Med. 127 (1997), 56-60

SANNA, S.; ASTRUC, J.M.; CARTA, A,; ROSATI, A.; BARILLET, F.: Simplification of the daily milk tesi-day recording in sheep. $29^{\text {in }}$ Biennial Session of ICAR, Ontario, Canada, July 31 - August 6, 1994

SAS:

Statistical Analysis System. User's Guide: Statistics, Version $6^{\text {th }}$ ed, SAS Institute Inc, Cary, NC, USA. 1996

WIGGANS, G.R.:

Method to estimate milk and fat yield from am/pm plans. J. Dairy Sci., 64 (1981), 1621-1624

WÖJTOWSKI, J.; GUT, A.:

Bestimmung der Anzahl und optimaler Haufigkeit der Milchkontrollen bei Schafen aus synthetischen Linie. 47th Annual Meeting of the European Association for Animal Production, Lillehammer, Norway, 2529.08.1996

WÖJTOWSKI, J; GUT, A.; KOZAL, E.; DANKÓW, R:

Correlations of results of goat milk control performed at different time intervals. $6^{\text {th }}$ International Symposium on the Milking of Small Ruminants. Athens, Greece, 26.09, - 01.10.1998. Wageningen Pers. EAAP Publication No 95: $478-482.1999$ 
WÓJTOWSKI, J; GUT, A.; ŚLÓSARZ, P.; DANKÓW, R:

Milchnulzung der Schafe in Niederungsgebieten Polens - Ergebnisse eines Forschungsmodellvorhabens. II VDL - Fachtagung „Forschung im Schafsektor", Martin-Luther-Universitat Halle-Wittenberg, 03-04.11.1999, $144-150$

Received: 2000-09-08

Acsepted: 2001-03-19

Nuthor's addresses

Doz. Dr. habil. JACEK WÓ,JTOWSKI, Prof. Dr. habil. ADAM GUT,

Dr. agr. PIOTR ŚLOSARZ

Agricultural University of Poznan

Department of Sheep and Goat Breeding

Zlotniki, ul. Sloneczna 1

62-002 Suchy Las

Poland

Tel. (fax): (004861) 8125520

E-mail: jacwoj@polbox.com

Prof. Dr. habil. KRZYSZTOF MOLIŃSKI

Agricultural University of Poznań

Department of Mathematical and Statistical Methods

ul. Wojska Polskiego 28

60-637 Poznan:

Poland

E-Mail: krys@owl.au.poznan.pl 
Arch. Tierz, Dummerstorf $\$ 4$ (2001) 3, 304

\title{
Buchbesprechung
}

\author{
Physikalische Therapie für Kleintiere
}

\author{
CECILE-SIMONE ALEXANDER (Hrsg.)
}

224 Seiten, 77 Abbildungen, 15 Tabellen, 18 Übersichten, Parey Buchverlag Berlin, im Blackwell Wissenschafts-Verlag, 2001

ISBN 3-8263-3320-9, DM 86,00; EUR 43,97; 0S 628,00; sFr 76,00

Der th:erapeutische Einsatz der Hände, vom Handauflegen bis zur Massage, stellt wohl die alteste physikalische Behandlungsform dar. Trotz der seit dem 19. Jahrhundert vereinzeit vorliegenden Zeitschriften- und Buchpublikationen, wurde diese Therapieform relativ wenig in der Veterinărmedizin angewendet. In dankenswerter Weise haben sich Herausgeber und das internationale Autorenkollektiv bemüht, in konzentrierter Form einen umfassenden Öberblick zum gegenwärtigen Wissens- und Erfahrungsstand in der Kleintierpraxis zu vermitteln. Klinische Vercrinarmedizin, als angewandte Wissenschaft, verfolgt das Ziel nach Beschreibung und Analyse in Form von Prophylaxe oder Therapien Lősungsmöglichkeiten aufzuzeigen. Erwähnt seien in diesem Zusammenhang $z$. B. ubberzeugende Erfolge der physikalischen Therapie in der Geriatrie oder der postoperativen Rehabilitation. Ais Teil dè klassisch-kilinischen Veterinărmedizin erfordert auch sie, wie bei anderen Maßnahmen einer erfolgreichen Anwendung, eine Ergănzung durch Disziplinen, die theoretisch oder praktisch dem vorliegenden Problemkreis zuzuordnen sind. Dieses generelle Konzept wird in dem vorliegenden Buch verwirklicht. So werden in den einfuhrenden Kapitoln die physiologischen Kenntnisse und Zusammenhänge der von der Physiotherapie betrofFenen Organsysteme vorgestellt. Sie werden durch ein kurzes Kapitel „Pathophysiologie des Bewegungsapparates $^{a}$ ergånzt. Eine besondere Stellung nimmt das Kapitel „Schmerz" ein, weil es einerseits die Zusammenhánge zu den kliniscihen Symptomen verdeutlicht, andererseits aber auch durch eine körpereigene-physiologischeSchrnetzkontroile eine mögliche Beziehung zur Physiotherapie aufzeigt. Nach den Kapiteln Elektrodiagnostik, Geschichre der Physiotherapie, welches man sich auch als Einführung des Buches vorstellen könnte und Befunderhebung, folgen die Massagen sowie physiotherapeutischen Techniken. Beschrieben werden hier z. B. die Traktion, Thermotherapie, Physiotherapie, Physiotechnik und Lichttherapie. Den Abschluß des Buches bildet das Kapitel „Indikationen" mit den Teilen kurative Praxis, Rehabilitation und Prophylaxe. Jedes Unterkapite! wird mis einem Literaturverzeichnis abgeschlossen. Dieses Buch ist detaillier geglieder und verfugi uber zahlTeiche, informative Abbiläungen, Tabellen und Úbersichten. Die praxisrelevanten, anwendungsorientierten, sich sui das Wesentliche beschränkenden, klaren Textaussagen sichern einen bohen Informationswert. Die im Buch vorgesteilten Erfahrungen, gewonnen in der veterinärmedizinischen Praxis, werden dazu beitragen, dass bei einer breiten Palette von Indikationen diese Methoden vermehrt getestet und zunehmend routinemäßig angewendet werden. Hierbei wird dieses Buch ein wertvoller Ratgeber und Anleitung zum Handein sein. 